\title{
Deceased's son fishing and fowling in the Old Kingdom tombs
}

\begin{abstract}
This article ${ }^{1}$ deals with the representations of the deceased's son fishing and fowling in the Old Kingdom tombs. There are fourteen examples in ten tombs. These scenes are found in the Memphis necropolis and the provincial cemeteries. The dating of the scene and purpose of its appearance within a certain time, the attire of the son, the fishing or fowling equipment, and accompanying inscriptions will be considered. Eleven significances of the scene will be suggested. The article will provide the reason for the spread of images of the son fishing rather than fowling, the reason for the son wearing the fillet and the streamer and the short kilt with the triangular apron. The reason for depicting the son, holding the spear at a straight/ slightly sloping horizontal angle being more common than holding it at a steep angle, will be guessed.
\end{abstract}

Volume 3 Issue 4 - 2018

\author{
Saleh Soleiman \\ Faculty of Archaeology, Damietta University, Egypt
}

Correspondence: Saleh Soleiman, Faculty of Archaeology, Damietta University, Egypt, Email saleh_suleiman82@yahoo.com

Received: July 30, 2018 | Published: August 21, 2018

\section{Introduction}

Fish were used for consumption as a cheap protein source, for wages and payment for the workmen, and as goods for trading with other commodities in the market. Fish were not intended for the tomb owner and were absent on the offering tables. Fish were not offered by the offering bearers because fish were not a valued food source for the high officials, and they had a bad smell. Fish were used as determinatives in the words meaning forbidden, impure and taboo. ${ }^{2}$ We have one scene in the tomb of Kagemni at Saqqara for the son of the deceased carrying two fish to his father. ${ }^{3}$ So, the fish are offered to the tomb owner, but this is rare and not preferred because the fish ate parts of the body of Osiris and the deceased becomes Osiris after his death. The scene of spear-fishing and/ or fowling belongs to the first theme of the fifteen themes of the Old Kingdom private tombs. ${ }^{4}$ The theme is marsh-related activities, which is divided into twenty eight different scenes. Fishing and fowling is the first one of these scenes. ${ }^{5}$ The depiction of the tomb owner as a spear fisherman and/or fowler is a very common scene. It can be found in about 96 Old Kingdom tombs; 93 were counted by Harpur, ${ }^{6}$ plus three others Inumin, Remni, ${ }^{8}$ and Ptahshepses. ${ }^{9}$

${ }^{1}$ I would like to thank Annette Gray and Dawn Sedgwick who reviewed the English of this article.

${ }^{2}$ Brewer DJ, Friedman RF. Fish and Fishing in Ancient Egypt. Cairo: 1990. p. $11-12,15$.

${ }^{3}$ Harpur Y, Scremin P. The Chapel of Kagemni - Scene Details. Egypt in Miniature. vol. I, Oxford: 2006. fig. 13; Soleiman S. 'An Attempt to Identify the Erased Figures of Offering Bearers in Some Scenes of Kagemni's Tomb at Saqqara'. In: Bárta M, Coppens F, Krejčí J, editors. Abusir and Saqqara in the year 2015. Prague: 2017. p. 393, fig 2.

${ }^{4}$ For these themes see; Oxford Expedition to Egypt (OEE) Database.

${ }^{5}$ For these activities see; Oxford Expedition to Egypt (OEE) Database, OEE. Themes and Scenes 1.

${ }^{6}$ OEE.1.1.

${ }^{7}$ Kanawati N. The Teti Cemetery at Saqqara. vol VIII, The Tomb of Inumin. Oxford: 2006. p. 30-32, 35-37, pls. 5-7, 12, 44, 46.

${ }^{8}$ Kanawati N. The Teti Cemetery at Saqqara. vol. IX, The Tomb of Remni.

Oxford: 2009. p. 24-29, pls. 45-47.

${ }^{9}$ Soleiman S, El-Batal A. The Gisr el-Mudir Cemetery at Saqqara. vol. IV, The Tomb of Ptahshepses. Part I, The Tomb Owner, Architecture and Dating of the
Family members appear with the deceased in fowling and/or fishingscenes in Old Kingdom tombs from the second half of the Fifth Dynasty ${ }^{10}$ onwards. ${ }^{11}$ There was a general desire in that period to bring to life scenes of daily life. ${ }^{12}$ They usually include one wife ${ }^{13}$ and rarely, two wives. ${ }^{14}$ Generally sons ${ }^{15}$ but rarely daughters ${ }^{16}$ accompany their fathers in the journey of fowling and/or fishing. Sometimes there are sons and daughters together. ${ }^{17}$ The family members stand

Tomb. Cairo: 2015. p. 82-84, p1s. 72-77.

${ }^{10}$ Moussa A, Altenmüller H. Das Grab des Nianchchnum und Chnumhotep. Mainz am Rhein: 1977. Abbs. 5,6, Taf. 74.

${ }^{11}$ Kanawati N, Abder-Raziq M. The Teti Cemetery at Saqqara. vol. V, The Tomb of Hesi. Warminster: 1999. pl. 50.

${ }^{12}$ Harpur Y. Decoration in Egyptian Tombs of the Old Kingdom. London and New York: 1987. p. 136.

${ }^{13}$ Schürmann W. Die Reliefs ausdem Grab des Pyramidenvorstehers Ii-nefert. Karlsruhe: 1983. p. 31-32, Abbs. 6, 21; Davies WV. et al. Saqqâra Tombs I. The Mastabas of Mereri and Wernu. London: 1984. p. 11, pls. 5, 8; Mcfarlane A. The Unis Cemetery at Saqqara. vol. I, The Tomb of Irukaptah. Sydney: 2000. p. 36-39, pls. 15, 41, 46; Moussa and Altenmüller. Nianchchnum. p. 58-61, 150-152, Taf. 4, 5, 74, 75, Abbs. 5, 6; Kanawati N. Deir El-Gebrawi. vol. II, Oxford: 2007. pls. 67, 68; Id., The Rock Tombs of El-Hawawish. The Cemetery of Akhmim. vol I, Sydney: 1980. p. 19-20, pl. 5, fig. 8; Id. The Tombs of El-Hagarsa. vol. III, Sydney: 1995. p. 38, pls. 14, 15, 42, 44, 45; Blackman MA. The Rock Tombs of Meir. Part IV, London: 1924. pls. vii, xvii; Fechheimer H. Die Plastik der Ägypter. Berlin: 1923. Taf. on p. 134.

${ }^{14}$ Myśliwiec K. et al. Saqqara I, The Tomb of Merefnebef. Warszawa: 2004. pl. xxi; Altenmüller H. Die Wanddarstellungen in Grab des Mehu in Saqqara. Mainz am Rhein: 1998. p. 98-105. Taf. 11,13; Moussa A, Junge F. Two Tombs of Craftsmen, Mainz am Rhein: 1975. p. 41-42, pl. 12.

${ }^{15}$ Myśliwiec K. et al. Merefnebef. pl. xxi; Davies et al. Mereri. p. 11, pls. 5, 8; Davies NG. The Rock Tombs of Deir el-Gebrâwi. Part II. London: 1902. p. 12-14, 29, 32, pls. iii-v, xxiii, xxviii; Kanawati N. Deir El-Gebrawi. vol. I, The Northern Cliff, Oxford: 2005. p. 50; Kanawati N. The Rock Tombs of ElHawawish. The Cemetery of Akhmim. vol. II, Sydney: 1981. p. 19-21, pl. 1, fig. 18; Blackman. Meir IV, pls. vii, xvii; Id. and Apted MR. The Rock Tombs of Meir. Part V, London: 1953. pls. xxiv, xxviii; Mohr HT. The Mastaba of Hetep-her-akhti. Leiden: 1943. p. 64-65, fig. 34.

${ }^{16}$ El-Khouli A, Kanawati N. Quseir el-Amarna, The Tombs of Pepy-ankh and Khewen-wekh. Sydney: 1989. p. 46-47. pls. 37-38; Kanawati. El-Hagarsa III. p. 38 , pls. $14,15,42,44,45$.

${ }^{17}$ Kanawati. Deir El-Gebrawi II, pls. 67, 68; Kanawati. The Rock Tombs of El-Hawawish. The Cemetery of Akhmim, vol. VI. Sydney: 1986. p. 11-12, 
behind or in front of the deceased, or may sit between his legs. ${ }^{18}$ Some Egyptologists suggest that the scene expresses a sexual union between the husband and his wife which is meant to guarantee his rebirth. ${ }^{19}$ Feucht refuted this idea because of the absence of the wife in some scenes. ${ }^{20}$ We agree with him and add that even if the wife exists, the existence of the children in the scene with the parents does not encourage sexual relations. Kessler suggested that the killing of the birds and fish is to the benefit of the dead on the New Year's feast of rejuvenation. ${ }^{21}$ If these two ideas (sexual union and rejuvenation) apply to the tomb owner, despite our reputation of the first interpretation and our reservation about the second, we cannot apply them to the son of the deceased fishing and fowlingin this case, because there is no wife depicted with him and he is already young and is not in need of rejuvenation. Feucht suggested that the deceased likes to catch fish and birds in the netherworld as he did in this world for pleasure and sustenance in the hereafter. ${ }^{22}$

We think that the scene reflects the desire of some or all of the family members (husband, wife, and children) to spend their free time together sharing in the activities of fishing and fowling. Sons are usually standing on the same skiff as the father, or on baselines above the bow or stern. ${ }^{23}$ We can guess the purpose of depicting them. Firstly, they are watching him to learn. They are collecting what their fathers catch, and holding the fishing and fowling equipment. Finally, they sometimes do this sport by themselves. This last action is the subject of this article.

\section{Representations of the deceased's son fishing and fowling}

The sons are usually depicted standing passively near the father fishing or fouling. One or two of them are shown as a miniature spear-bearers/fowlers on the baseline above the bow of the skiff or on a wooden deck on the father's papyrus skiff.$^{24}$ This wooden deck had better footing for distribution of weight on the skiff. ${ }^{25}$ Below the vessel is a band representing water and before the figure is a clump of papyrus representing the thicket. We have about fourteen examples in ten tombs of the sons fishing and/or fowling with their fathers from a

pl. 1, fig. 3; Id., El-Hagarsa III. p. 17-18, pls. 5, 28-30; Id. and Abder-Raziq Hesi. p. 25-27, pl. 53; Van de Walle B. La Chapellefunéraire de Neferiretenef. Brussels: 1978. p. 65-69, pl. 1; Altenmüller, Mehu, Taf. 13; Moussa and Altenmüller, Nianchchnum, p. 58-61, Taf. 4, 5, Abbs. 5, 6; De Morgan J. Fouilles à Dahchour en 1894-1895. Vol II, Vienna: 1903. p. 4, pl. xxiv; Id. et al., Catalogue des monuments et inscriptions de l'Égypte Antique, Première série, Haute Égypte. Tome I, De la frontière de Nubie á Kom Ombos.Vienna : 1894.fig. on p. 146.

${ }^{18}$ Feucht E. Fishing and Fowling with the Spear and the Throw-stick Reconsidered. The intellectual Heritage of Egypt: Studia Aegyotuaca XIV, Budapest: 1992. p. 157-158.

${ }^{19}$ Westendorf $\quad$ W. 'BemerkungenzurKammer der WiedergeburtimTutanchamungrab'. In: ZÄS 94 (1967), p. 139; LÄ. IV, 1052; Vanek S. 'The Archaeology, Geography and History of the Egyptian Delta in Pharaonic Times'. In: DE I (1989), p. 314; Buchberger H. 'Sexualität und Harfenspiel'. In: GM 66 (1983), p. 23.

${ }^{20}$ Feucht. Fishing. p. 160-165.

${ }^{21}$ Kessler D. 'Zu den Jagdszenen auf demkleinengoldenenTutanchamunschrein'. In: GM 90 (1986), p. 35.

${ }^{22}$ Feucht. Fishing. p. 168.

${ }^{23}$ Harpur. Decoration. p. 140

${ }^{24}$ Vandier J. Manuel d'archéologieégyptienne IV. Paris: 1964. figs. 399, 401, 407; Harpur, Decoration, 140; Id. and Scremin. Kagemni. p. 386 [detail 125]. ${ }^{25}$ Kanawati N, Abder-Raziq M. The Teti Cemetery at Saqqara. vol. VI, The Tomb of Nikauisesi. Warminster: 2000, p. 38. total of 96 tombs. These tombs are:

a. Seshemnefer IV LG 53, GIS, Giza. ${ }^{26}$

b. Nekhebu G 2381, West Field, Giza. ${ }^{27}$

c. Remni, Teti cemetery, Saqqara. ${ }^{28}$

d. Hermeru, Unas cemetery, Saqqara. ${ }^{29}$ (Figure 1)

e. Ptahshepses, a recently discovered tomb located in the Gisr El-Mudir, west of the Step Pyramid, Saqqara. ${ }^{30}$ (Figure 2) (Figure 3)

f. Tomb of unknown person, Saqqara. ${ }^{31}$

g. In-sneferu-ishtef, Dahshur. ${ }^{32}$ (Figure 4)

h. Niankhpepy, Zawet el-Maiyetin..$^{33}$

i. Ibi, Deir El-Gebrawi. ${ }^{34}$

j. Hesi-Min F 1, El-Hawawish. ${ }^{35}$

The scene is not common and appears more often in the Memphis necropolis (seven tombs) than the provincial cemeteries (three tombs). It is more connected to Saqqara (four tombs) than any other cemetery (two tombs at Giza, one tomb at each of the other cemeteries). The oldest attestation of this scene is in the tomb Seshemnefer IV at Giza, about which there are different opinions about dating. It is dated to the reign of Izezi ${ }^{36}$ Ulnas ${ }^{37}$ Unas' and Teti's reigns, ${ }^{38}$ or Sixth Dynasty. ${ }^{39}$ The second tomb, which shares in including the oldest attestation of the scene, is Ptahshepses at Saqqara. It is dated to Unas and Teti. ${ }^{40}$ Some of its scenes were executed in the reign of Unas and other scenes were executed in the reign of Teti. The name of Teti is mentioned on the wall next to the fishing and fowling scene. This means that the decoration of this wall was executed in the reign of Teti,which is why the representation of the son fishing and fowling in the tomb of Ptahshepses is dated to Teti's reigns. There is no depiction for the son fishing or fowling in the scenes of the deceased fishing and/or fowling, which are dated to Izezi or Unas, such as Zaib G 2092, G 2093, ${ }^{41}$ Senedjemib/Inti G 2370, ${ }^{42}$ Senedjemib/Mehi

${ }^{26} \mathrm{PM}$. III'2, 223; Junker. Gîza. XI. fig. 60.

${ }^{27}$ PM. III ${ }^{2}$, 89-90 [3]; Smith WS. 'The judge goes fishing', In: BMFA 56 (1958), p. 58-60, fig. 2.

${ }^{28}$ Kanawati. Remni. pl. 46.

${ }^{29}$ PM. III ${ }^{2}$, 626; Hassan, S., Excavations at Saqqara 1937-1938, vol III, Mastabas of Princess Hemet-Re and Others. Cairo: 1975. p. 79, fig. 42. ${ }^{30}$ Soleiman and El-Batal. Ptahshepses. Part I, p. 82-84, pls. 72-77.

${ }^{31}$ PM. III' ${ }^{2}$, 654; Quibell JE. Excavations at Saqqara (1907- 1908). Cairo: 1909. p. 112 [3], pl. li.

${ }^{32} \mathrm{PM}$. III' ${ }^{2}$, 891; De Morgan. Dahchour. vol. II, 4, pl. xxiv.

${ }^{33}$ PM. IV1, 137-138; Varille A. La Tombe de Ni-Ankh-Pepi à Zâouyet elMayetîn. Cairo: 1938. p. 12-13, pls. v, ix.

${ }^{34}$ PM. IV1, 243-244; Kanawati. Deir El-Gebrawi II, pls. 67, 68

${ }^{35}$ Kanawati N. The Rock Tombs of El-Hawawish. The Cemetery of Akhmim. vol. IV, Sydney: 1986. p. 19-21, pls. 2, 3, figs. 12, 13.

${ }^{36}$ Cherpion N. Mastabas et hypogées d'Ancien Empire - Le probléme de la datation. Brussels: 1989. p. 229, 234.

${ }^{37}$ Baer K. Rank and Title in the Old Kingdom. Chicago: 1960. p. 293.

${ }^{38}$ Harpur. Decoration. p. 307, 315, 321, 335; Oxford Expedition to Egypt (OEE) Database, OEE.Tombs.

${ }^{39}$ Kloth N. Die (auto-) biographischen Inschriften des ägyptischen Alten Reiches: Untersuchngen zu Phraseologie und Entwicklung. BSAK 8, Hamburg: 2002. p. 34.

${ }^{40}$ Soleiman and El-Batal. Ptahshepses I, p. 77-99.

${ }^{41}$ PM. III', 70; Roth AM. Giza Mastabas. vol. 6, A Cemetery of Palace Attendants. Including G 2084-2099, G $2230+2231$, and G 2240, Boston: 1995. p. 111, pls. 73, 185.

${ }^{42}$ Brovarski E. Giza Mastabas VII. The Senedjemib Complex I. Boston: 2000. 
G $2378,{ }^{43}$ and Iynefert ${ }^{44}$ at Giza, Kaemnefert D $23,{ }^{45}$ Rashepses LS $16,{ }^{46}$ Neferirtenef D 55, ${ }^{47}$ Dauhep D 59, ${ }^{48}$ Duaenre D $61,{ }^{49}$ Iynefert, ${ }^{50}$ Irukaptah, ${ }^{51}$ Neferseshemptah and Sekhentiu, ${ }^{52}$ Irenkaptah $^{53}$ and the tomb of unknown person ${ }^{54}$ at Saqqara, Khunes no. 2 at Zawet elMaiyetin ${ }^{55}$ and Werirni at Sheikh Said. ${ }^{56}$ When we examine the scenes of the deceased fishing and/ or fowling-, which are dated to Teti, such as the tomb of In-sneferu-ishtef and the tomb of unknown person at Saqqara (No. 6), there is a depiction of the son fishing or fowling. The scene is found from the reign of Teti, not from the reign of Unas as had been suggested. ${ }^{57}$ This scene continued in the Sixth Dynasty to the end of the Old Kingdom. The scene may have appeared at that time because of the increased size of the tomb and the large space dedicated to decoration, which allowed for increased scenes details. The father may have wanted his eldest son to participate in all his works in order to win the satisfaction and the kindness of the son who would be responsible for the family after his death. This may have included the establishment of the rituals and ceremonies of his father for after his death. The depiction of the eldest son on most of the tomb walls would also keep him preserving the tomb of his father. It would protect it from defilement by human beings, especially in that period of the destruction of the tombs which appeared: reusing their stones, reusing the tombs for burial, opening the sarcophagus, attacking and harassing the funerary priests, and stealing the funerary meals. ${ }^{58}$

The representations of the son fishing and fowling usually show him face-to-face on the same wall. The son is depicted on one side as a fisher and on the other as a fowler. They are separated by an entrance and papyrus thicket (Seshemnefer IV and Ibi) or by papyrus thicket only (Ptahshepses and In-sneferu-ishtef). The depiction of the son fishing is more common than the son fowling; whereas the first is found in ten tombs, the second appears only in four tombs (Seshemnefer IV, Ptahshepses, In-sneferu-ishtef and Ibi). This is because of the religious and ideological significance of the fishing, which will be explained later. The figure of the son is sometimes depicted fishing only, or fishing and fowling together. Sometimes the same song is depicted doing both activities (Ibi), other times the two eldest sons are shown (Ptahshepses). The son is represented with a collar (Remni, Ptahshepses, tomb of unknown person [Quibell, figs. 24-27.

${ }^{43}$ Ibid, figs. 100-103.

${ }^{44}$ PM. III ${ }^{2}$, 298-299; Schürmann. Ii-nefert. p. 31-32, figs. 6, 21

${ }^{45}$ Simpson WK. The Offering Chapel of Kayemnofert in the Museum of Fine Arts. Boston: 1992. p. 4-7, fig. 4, pl. A.

${ }^{46}$ LD. II, 60.

${ }^{47}$ Van de Walle. Neferiretenef. p. 65-69, pls. 1, 20.

${ }^{48}$ Mariette A. Les mastabas de l'Ancien Empire. Paris: 1889. p. 338-339.

${ }^{49} \mathrm{Ibid}$, p. 350

${ }^{50}$ Kanawati N, Abder-Raziq M. The Unis Cemetery at Saqqara. vol. II, The Tombs of Iynefert and Ihy (reused by Idut). Oxford: 2003. p. 18-19, pl. 37 [b].

${ }^{51}$ Mcfarlane. Irukaptah. pls. 15, 41, 46.

${ }^{52}$ Moussa and Junge. Craftsmen. p. 22-23, pl. 6.

${ }^{53}$ Ibid, p. 41-42, pl. 12.

${ }^{54}$ Ziegler C. Catalogue des stèles, peintureset reliefs égyptiens de l'Ancien Empire et de la Première Période Intermédiaire vers 2686-2040 avant J.-C. Paris: 1990. p. 298-301.

${ }^{55}$ PM. IV ${ }^{1}$, 134-135; LD. II, 106 [a]; Varille. Ni-Ankh-Pepi. p. 12, fig. 4.

${ }^{56}$ Davies N. de G. The Rock Tombs of Sheikh Saïd. London: 1901. p. 23, pl. xi.

${ }^{57}$ Harpur. Decoration. p. 136.

${ }^{58}$ For the texts of destruction of the tombs and reusing their stones see our study: Soleiman S. The Self Talks and Appeal to the Living in the Old Kingdom Private Tombs at Memphis Necropolis. Cultural-Analyzing Study, PhD Thesis, Archaeology and Culture Department, Faculty of Arts, Helwan University, Cairo: 2014. unpublished, p. 608-611.
Saqqara 1907-1908, pl. Li], In-sniffer-ishtef and Ibi). This collar is long and hanging down in front of the breast. According to Cherpion, it appears in tomb illustrations from the time of Cheops to the reign of Pepy I. ${ }^{59}$ We disagree with Cherpion, and think this collar continued after the reign of Pepy I. It is found in the fowling and fishing scene of Djau, son of Ibi at Deir El-Gebrawi, which is dated to Pepy II's reign. ${ }^{60}$ The son may also be shown with bracelets (Ptahshepses and Ibi)

The son is depicted with a fillet and a streamer (Nekhebu, Ptahshepses, tomb of an unknown person at Saqqara and IBI). The fillet consisted of linen tied in a bow at the back of the head. It was replaced by metal bands, and in the Fifth Dynasty was made of precious materials. ${ }^{61}$ We believe that wearing the fillet and the streamer was in imitation of the kings who were wearing the same dress in the activities of fishing and fowling, as did Userkaf. ${ }^{62} \mathrm{We}$ think also that the fillet and the streamer served to keep the wig in place. One disadvantage for the fisher and fowler was gusting wind, which could have dislodged the wig. The fillet and a streamer may have stopped him from having to cast his wig aside and do the activity bareheaded. The sons are generally shown in the Old Kingdom tombs as naked children or clothed adults. The son fishing and/or fowling is usually depicted as an adult wearing a certain kilt. This consists of a short kilt and a trapezoidal apron with straight lateral edges widening towards its lower end. It is almost triangular in shape. It is plain and held by a sash tied with a frontal loop. This kilt is termed marshhunting dress. It is one of the three kilts that the deceased wears when he is depicted fishing and fowling in the Old Kingdom. It is known from the reign of Izezi onwards ${ }^{63}$ (Senedjemib/ Inti, and IynefertMenkaure cemetery at Giza, Neferirtenef D 55and Reshapes LS 16 at Saqqara). The combination of two items of clothing of the kilt was preferred because it enabled free movement. ${ }^{64}$

The general idea of the shape of the son's kilt is taken from the royal kilt, as this scene was originally a royal subject. It was intended to distinguish the individual's kilt from that used by kings and gods. Zelenkováhas suggested three features, two of which are accepted. Firstly, the apron is generally trapezoidal with its lower edge wider than the upper one. Secondly, the kilt is held by a slash and regularly features a frontal loop. Thirdly, Zelenková suggests the kilt worn by the high officials is plain and never pleated as does the royal kilt. ${ }^{65}$ We cannot accept last one because royal kilts are sometimes plain and not pleated, as is the royal kilt of the famous statue of Menkaure and his wife, now in the Boston Museum. The son engaged in fowling is holding the decoy birds in his frontal hand and the throwing stick in the rear hand. The son fishing is usually holding the spear with his two hands. The two speared fish are the usual Tilapia and Lates. ${ }^{66}$ This is an interesting combination because the first kind would be

${ }^{59}$ Cherpion, Mastabas. p. 60-62, 183-184, figs. 51, 52.

${ }^{60} \mathrm{http}: / /$ www.Oxfordexpeditiontoegypt.com/Data base.php> Scene-details Database: Tombs (p. 20); Kanawati. Deir El-Gebrawi II, p. 19.

${ }^{61}$ Kantor HJ. Plant Ornament in the Ancient Near East. Chicago: 1999. p. 41. ${ }^{62}$ Labrousse A, Lauer J. Les complexes funéraires d'Ouserkafet de Néferhétepès. Vol. 2, Cairo: 2000. figs. 99-101.

${ }^{63}$ Zelenková L. 'The Royal Kilt in non-Royal Iconography?The Tomb Owner Fowling and Spear-Fishing in the Old and Middle Kingdom'. In: BACE 21(2010). p. 142-145, figs. 2.1-2.6.

${ }^{64}$ Bonnet H. Die Ägyptische Tracht bis zum Ende des Neuen Reiches. . Leipzig: 1917. p. 11.

${ }^{65}$ Zelenková. Royal Kilt. p. 142. figs. 2.1-2.6

${ }^{66}$ Gamer- Wallert. I. Fische und Fischkulte im alten Ägypten. Wiesbaden: 1970. p. 129 , pls. $5-6$. 
most abundant in the swampy shallow water area of the Delta, while the second kind would be in Upper Egypt. So the scene has political significance as artists tried to portray the unity of the two lands. What confirms this idea is that the oldest attestation of the fowling and fishing scene comes from the Mortuary temple of Userkaf at Saqqara,${ }^{67}$ then the Mortuary temple of Sahure ${ }^{68}$ and the Valley temple of Niuserre at Abusir. ${ }^{69}$ In these, the king is doing these activities by himself. We do not agree with Feucht, who believes that the oldest depiction of this scene is in the tomb of Nebemakhet LG $86 .{ }^{70}$ In this scene the activity is not fowling, but it is pulling papyrus.

The Tilapia is known in Egypt as Bolti and inhabits the inshore waters. The Lates have a strongly serrated preoperculum, and an operculum ending in a spine. They prefer deep, well oxygenated waters. They were caught in the winter than in the summer, because in the winter they come near the surface or into the shallow water, but in the summer they keep to the cooler deeper water. ${ }^{71}$ When fishing, the son is depicted holding the spear at a straight/ slightly sloping horizontal angle (Nekhebu, Ptahshepses, Remni, Hermeru, the tomb of an unknown person at Saqqara, Niankhpepyand Ibi), or a steep angle (In-sneferu-ishtefand Hesi-Min). The former is more common than the second angle. It looks like the traditional, common position of the tomb owner of the Old Kingdom, where he holds the spear almost horizontally. ${ }^{72}$ We think the reason for this will be in line with the tradition of portraying the greatness and pride of the tomb owner;He is looking in front of him and after him his son, who inherits the same arrogance, pride, and greatness, rather than depicted as bending and looking down. There are usually some identifying inscriptions accompanying the son. These inscriptions consist of a word which refers to his relation to the tomb owner, his titles, epithets, and his name (Nekhebu, Ptahshepses, Remni, In-sneferu-ishtef, Ibi and Hesi).

The son is usually identified as z3.f smsw mry.f 'his eldest son, his beloved'. McCorquodale

suggested that the term eldest $s m s w$ described the eldest surviving son or daughter, or might apply to any child chosen as the heir of the tomb owner. It has been suggested that the purpose of referring to a child as the $s m s w$ is to identify that child as the inheritor of the parent's (mother or father) property. During the New Kingdom, 'the eldest son $z 3 \mathrm{smsw}$ seems to have received double the portion of the inheritance that his siblings received, presumably because he was responsible for the burial of his parents'. ${ }^{73}$

We have, in the fishing and fowling scene of Ptahshepses, both sons with the same definition $z 3 . f s m s w$. There are three possibilities: two of them are suggested by Harpur and Kanawati; perhaps the sons are twins; or the deceased married two wives and each son was the eldest son of his mother. ${ }^{74}$ High officials have tended to combine more

${ }^{67}$ Smith WS. A History of Egyptian Sculpture and Painting in the Old Kingdom. New York. 1978. pl. 52; Labrousse and Lauer. Ouserkaf. vol. 2, figs. 99, 100.

${ }^{68}$ Borchardt L.Das Grabdenkmal des Königs S'ahu-Re. II, Leipzig: 1913. Taf. 16.

${ }^{69}$ Borchardt L. Das Grabdenkmal des Königs Ne-user-re. II, Leipzig: 1907. Abb. 16.

${ }^{70}$ Feucht. Fishing. p. 160, 168, fig. 1; LD. II, 12.

${ }^{71}$ Brewer and Friedman. Fish. p. 11, 74, 77-79.

${ }^{72}$ Vandier, Manuel. IV.720.

${ }^{73}$ McCorquodale K. Representations of the Family in the Old Kingdom: Women and Marriage. Sydney: 2010. p. 194-196.

${ }^{74}$ Harpur Y, Scremin P. The Chapel of Ptahhotep - Scene Details. Oxford: 2008. than one wife to increase relationships between powerful families. They married one wife after losing the other, by death or divorce, in succeeding marriages. ${ }^{75}$ This probably means that Ptahshepses married two wives. The fact that only one of them is depicted, may mean that the other wife was dead or divorced before the tomb was decorated. Alternatively, we suggest the third interpretation. It is that the eldest son could have died before the younger, so that his brother became the eldest. We have other examples ${ }^{76}$ where this situation occurred.

The depiction of the son as a spear bearer or fowler is an imitation of his father, ${ }^{77}$ who is depicted in the same scene doing the same action. It could also be that the son is being trained in the arts of fishing and fowling to gain the necessary experience. This scene is a kind of sport, an activity for fun, and for spending free time with the rest of the family. The scene expresses the son's role in providing family members with food. The son and before him his father wants to imitate the king in some of his activities. This scene represents the Osirion myth and Osirion triad: the deceased himself is Osiris, the son is Horus, and the wife is Isis. The son is fishing to revenge to his father by catching the fish, that ate parts of the body of Osiris and which represent the followers of Seth. The place of doing this activity is the marshes, which refers to the Delta, where some of the events of the story of Osiris took place. The fact that Osiris was used as an epithet of the deceased, before his name, from the middle part of the reign of Pepy II ${ }^{78}$ also lends credence to this theory. Now we understand why the depiction of the son fishing is more common than the son fowling because of the religious and ideological significance of this action.

When we check the autobiography and appeal to the living, we can see the concern of the deceased for doing justice, rightness and order. The deceased and son fishing means that they destroy and get rid of followers of Seth, the evil spirits. This means they do justice, rightness and order. The deceased also refers in his texts to doing what the king loves. The fishing was one of the activities that the king likes to do since the early Fifth Dynasty. We agree with Keyser, who suggested that the deceased fowling and fishing identifies himself with the king. ${ }^{79}$ At the end, we disagree with Brewer and Friedman, who suggest that the fish depicted in the tomb were not of significance, and that the fish were just to represent the activities of daily life. ${ }^{80}$ The depiction of the fish has a deep meaning. It has a political, religious and ideological significance.

p. 319 [Details 225-227].

${ }^{75}$ Kanawati N. 'The Mentioning of More than One Eldest Child in Old

Kingdom Inscriptions, In: CdE 51 (1976). p. 235-251.

${ }^{76}$ For these examples see: McCorquodale. Family. p. 202-241; Davies NG. The Mastaba of Ptahhetep and Akhethetep. Part II, London: 1901. pls. iv, xiii, xiv, xviii, xx, xiv; Paget RFE, Pirie AA. 'The Tomb of Ptahhetep', In: Quibell JE, editor. The Ramesseum. London: 1898. p. 25-36, pls. xxxi, xxxii; Kanawati and Abder-Raziq. Nikauisesi. pls. 43-46, 48, 49, 52, 54.

${ }^{77}$ Harpur. Decoration. p. 136.

${ }^{78}$ See these texts: Jéquier G. Tombeaux de particuliers contemporains de Pepy II. Fouilles à Saqqarah. Service des Antiquités de l’Égypte. Cairo: 1929. figs. 14, 15, 48; Brovarski E. 'The Late Old Kingdom at South Saqqara'. In: Pantalacci L, Berger-el-Naggar CH, editors. Des Néferkarê aux Montouhotep. Travaux archéologiques sur la fin de la VIe dynastie et la première Période Intermédiaire. Actes du Colloque CNRS - Université Lumière-Lyon 2, tenu le 5-7 juillet 2001 Travaux de la Maison de l'Orient et de la Méditerranée. No 40. Lyon: 2005. p. 63.

${ }^{79}$ Keyser E. 'Scenes de chasse et peche'. In: CdE 43 (1947). p. 48.

${ }^{80}$ Brewer and Friedman. Fish. p. 12. 


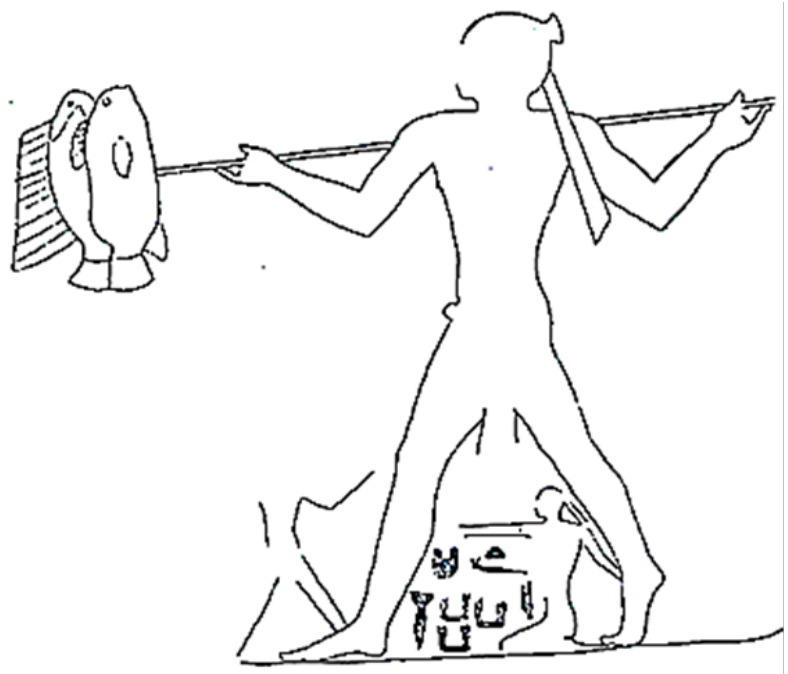

Figure I Hermeru's fishing scene (after Hassan. Saqqara. III. fig. 42).



Figure 2A Ptahshepses's fishing scene (after Soleiman S, El-Batal A.The Tomb of Ptahshepses. Part I, Cairo: 20I5. pl. 89).

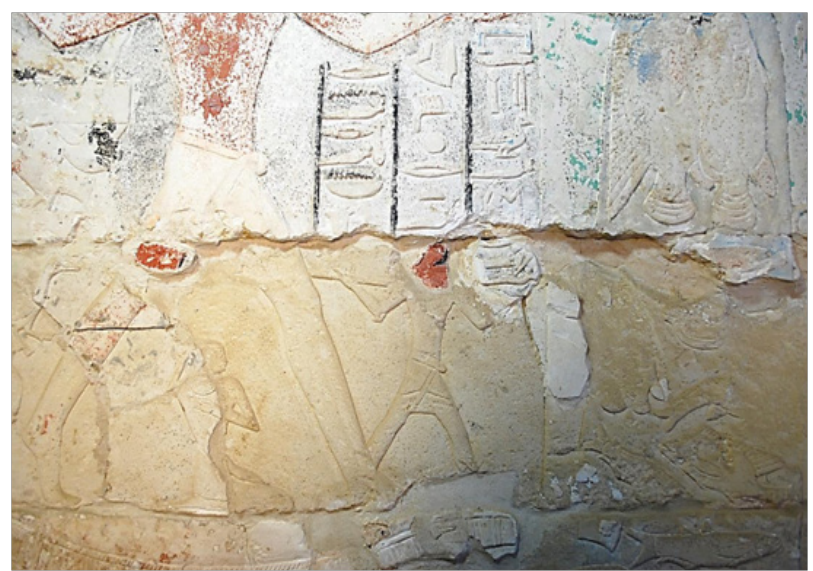

Figure 2B Ptahshepses's fishing scene (after Soleiman and El-Batal. Ptahshepses. Part I, pl. 9I). 


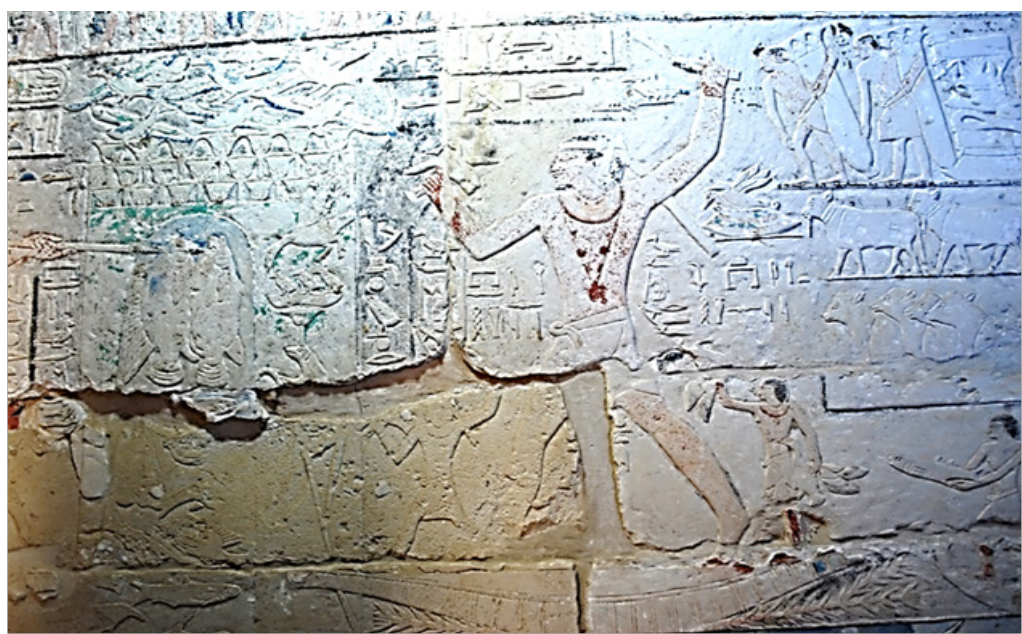

Figure 3A Ptahshepses's fowling scene (after Soleiman and El-Batal. Ptahshepses. Part I, pl. 92).

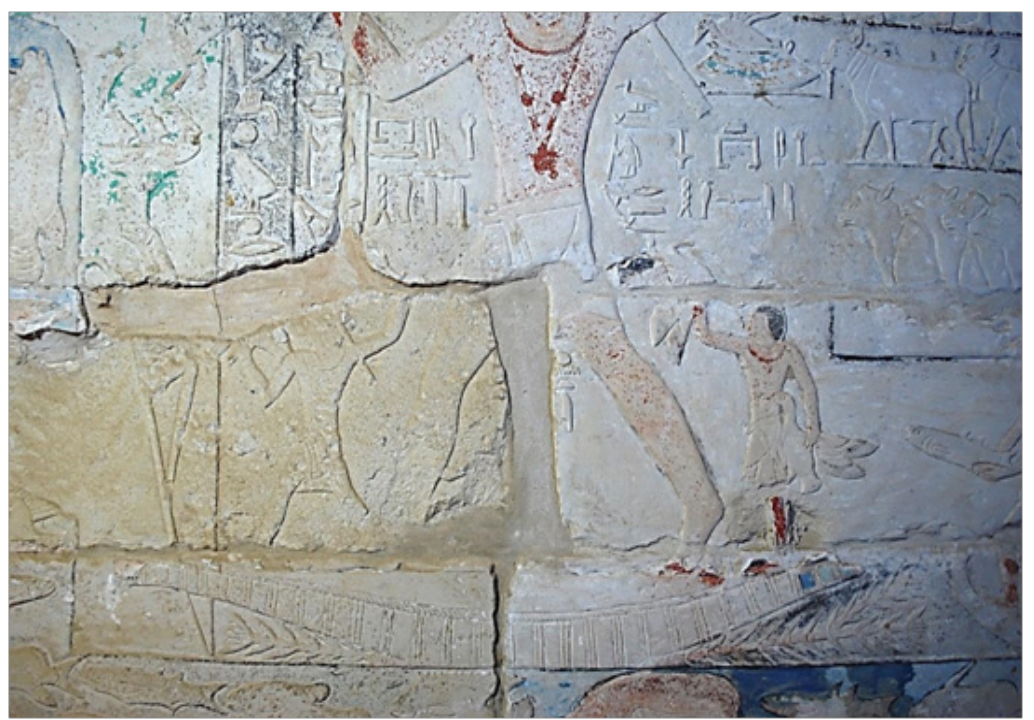

Figure 3B Ptahshepses's fowling scene (after Soleiman and El-Batal. Ptahshepses. Part I, pl. 94).

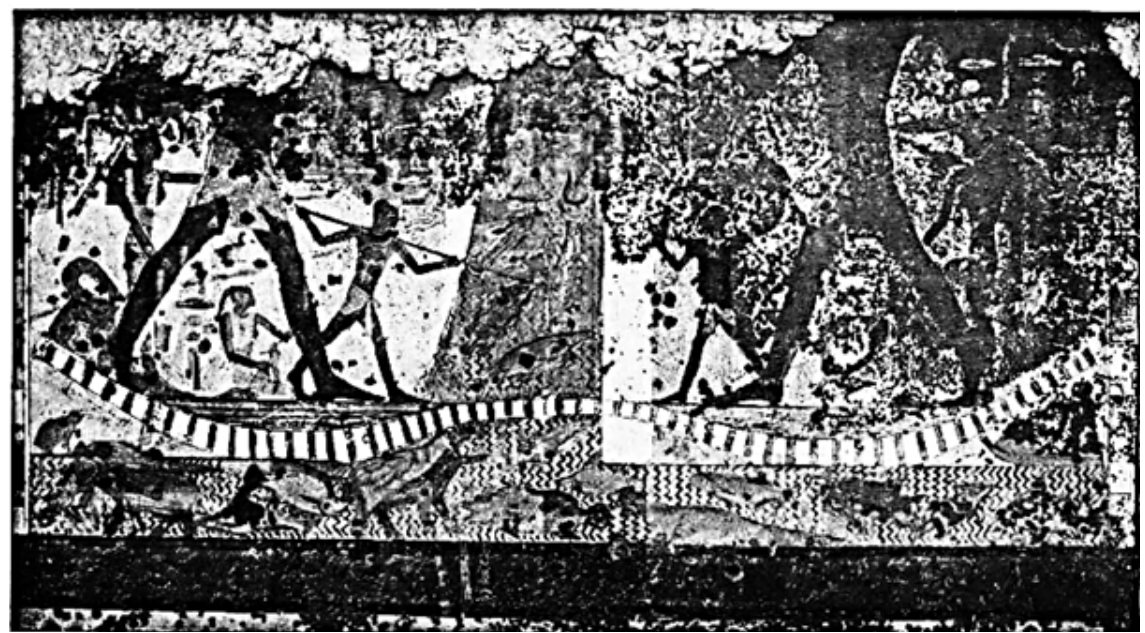

Figure 4 In-sneferu-ishtef's fishing and fowling scene (after de Morgan J. Fouilles à Dahchour en I894-1895. vol. II.Vienna: 1903. pl. xxiv). 


\section{Conclusion}

Family members are depicted with the deceased fishing and fowling to reflect the desire of family members to spend free time together and their desire to be together in the second life as they were in the first life.

a. There are four purposes for depicting the sons with his father fishing and fowling. Firstly, they are watching him to learn. Secondly, they are collecting what their fathers catch. Thirdly, they are holding the fishing and fowling equipment. Fourthly, they sometimes do this sport themselves.

b. There are about fourteen scenes in ten tombs of the sons fishing and/ or fowling with their fathers.

c. This scene appears more frequently in the Memphis necropolis than in the provincial cemeteries. It is more connected to Saqqara.

d. The first known appearances of this scene are dated to Teti's reign and, not from the reign of Unas as it was previously thought.

e. The scene continued during the Sixth Dynasty to the end of the Old Kingdom because of the increased size of the tomb and the large space dedicated to decoration.

f. The representations of the son fishing and fowling are usually depicted face-to-face on the same wall. They are separated by an entrance and papyrus thicket, or by papyrus thicket only.

g. The depiction of the son fishing is more common than his depiction fowling because of the religious and ideological significance of the fishing. The son fishing can also be found without his figure fowling. But the latter is never represented without the first.

h. Sometimes the same son is depicted doing both activities; at other times the two eldest sons are shown.

i. The son could be represented with the collar and bracelets. The collar appears in general from the reign of Cheops to the reign of Pepy II, not to the reign of Pepy I as was thought.

j. The son could be depicted with the fillet and the streamer to keep the wig in place.

k. He is usually depicted wearing a short kilt with the triangular apron, the same kilt that the tomb owner wears whilst fishing or fowling from the reign of Izezi onwards. The shape of kilt is taken from the royal kilt because this scene was originally a royal subject.

1. The son fowling holds in his frontal hand the decoy birds and in the rear hand the throwing stick. The son fishing is usually holding the spear with his two hands.

m. The scene has a political significance. The two speared fish are the usual Tilapia and Lates referring to Upper and Lower Egypt. The scene portrays the unity of the two lands. What confirms this previous idea is that the oldest attestation of the fowling and fishing scene comes from royal reliefs where the king is doing these activities by himself.

n. The son is depicted holding the spear at a straight/ slightly sloping horizontal angle, or a steep angle. The first position is more common than the second for the deceased and his son to show the greatness and pride of the tomb owner.He is looking in front of him, and after him his son, who inherits the same arrogance, pride, and greatness, instead of being depicted as bending and looking down.

o. The inscriptions accompanying the son identify him. They consist of a word which refers to his relation to the tomb owner, his titles, epithets and his name.

p. The depiction of two eldest sons fishing and fowling may be interpreted by three possibilities, not only two as it was suggested previously.

q. The purpose of the depiction of the son fishing and fowling is:

a. Filling the increased space dedicated to decoration.

b. The father wants his son sharing his activities to win the satisfaction and the kindness of the sun to do the rituals and ceremonies for his father when he dies.

c. To preserve the tomb of his father and protect it from defilement by human beings, which was common in that period.

d. An imitation of his father, who is depicted in the same scene doing the same action

e. An imitation of the king, who is depicted first doing the same action.

f. Training in the arts of fishing and fowling to gain the necessary experience.

g. A kind of sport for fun and for spending free time with the rest of the family.

h. Providing family members with food.

i. The political significance of the scene which portrays the unity of the two lands.

j. The religious and ideological significance of this action, which represents the Osirion myth and the conflict between good and evil and the victory of good over evil.

k. The scene represents the Osirion triad.

r. This scene was originally a royal subject. It is used later by officials. So it has some royal features such as the kilt, the fillet and the streamer. It has a political significance with the two kinds of fish, and a religious significance connected with the king who, after his death was Osiris, and in his life was Horus.

\section{Acknowledgements}

Our special thanks go to JHAAS Editors for their support, Annette Gray and Dawn Sedgwick, who reviewed the English of this article and to my colleague Dr. Sabry Badea

\section{Conflict of interest}

Author declares that there is no conflict of interest. 